\title{
Fangsheng (放生) and its Critical Discourse on Environmental Ethics in Buddhist Media
}

\author{
Latifah $^{1 *}$, Ary Budiyanto ${ }^{2}$ \\ ${ }^{1}$ STAB Kertarajasa, Malang, Indonesia, ${ }^{2}$ Universitas Brawijaya, Malang, Indonesia \\ *<efi_latifah@yahoo.com>
}

\begin{abstract}
Religious views of a community group are very influential in determining their attitudes and behavior towards nature and the environment. On the one hand, there is a worldview correlation that affects attitudes that are less friendly to nature as well as human superiority among other creatures that makes it feel entitled to exploit nature. On the other hand, religious views are also a motivation for caring for and loving nature, as is the will of Buddhists to create happiness for all living things. Reflections on choosing a moderate way of life prevent greed that can cause damage to nature so that sustainable development can be realized. The media, especially digital media, represents the implementation of Buddhist environmental ethics in a variety of writing frames. This study aims to look at Fangshen (放生) ritual in critical discourse on environmental ethics perspective as representated in Indonesian Buddhist media such as Buddhazine, Kompasiana, Tionghoa.info, and etcetera. This research shows that the discourse on environmental ethics in Buddhist media is at the point of intersection between natural disasters as a result of karma (kamma), paramita funds to change karma, responsibility for protecting nature, and compassion for all beings.
\end{abstract}

Keywords: Fangshen, environment ethics, Indonesian Buddhist media

\section{Introduction}

"May all beings be free from enmity; may all beings be free from injury; may all beings be free from suffering; may all beings be happy." Buddhist ethical teachings spread love to the universe, not only for the benefit of humanity, but for all beings.
Moreover, even humans are not a separate part of nature, as Thich Nhat Hanh teaches, "The Earth is not just our environment. We are the Earth and the Earth is us. We have always been one with the Earth."

Thus, Buddha not only teaches to preserve nature into our living space, 
but also makes ourselves part of nature, we can feel the hardness of the stone; the flow of wind and water; and the heat of fire as part of mindfulness training. This Buddhist Enviromental ethics can be seen from the news, opinions, and articles of Buddhist media that not only show representation, but also how the construction of Buddhist moral practices. This paper will look at how Buddhist media convey moral messages related to environmental issues both manifested in rituals, how to respond to disasters, and preserve the environment. Through critical discourse analysis, this paper not only aims to describe the representation of Buddhist media on the environment, but also looks critically at the text as a form of Buddhist moral practice as a contextual reconstruction of Buddhist teachings by looking at discourse and implementation of Fangsheng rituals in Indonesian Buddhist Media.

\section{Method}

The critical discourse analysis method reveals the structure of rationality along with the latent ideology contained in the text by combining three aspects namely text analysis, production process analysis, and sociocultural analysis that develops around the discourse.[1] The quality of critical discourse analysis is determined by its ability to place the text in its context intact through the linkage between analysis at the text level and analysis of the context at a higher level. [2]

In this paper, critical discourse analysis shows not only how representations of Buddhist ritual practices, especially Fangsheng, and attitudes towards disaster in Buddhist media, but also relate them to the macro context hidden behind the text as an effort to raise awareness, and social transformation towards environmental problems nowadays.

In general, discourse analysis is applied to news analysis in the mass media to show the hidden ideology behind the news. However, in its development a critical analysis of discourse was also carried out to analyze the text of religious lectures, for example to criticize gender or religious discrimination. In this paper, critical discourse analysis is applied to articles published in Buddhist media, specifically Buddhazine, Kompasiana, Tionghoa.info, etcetera and its intertextual relations with other media, such as Kompasiana, to see a broader context.

\section{Analysis and Finding}

Social media gives space to publicize religious rituals to the public realm that were previously more spiritual in nature. On the one hand, this has a positive meaning because it can increase motivation in religious practices and increase religious literacy for other people. However, on the 
other hand, this can shift the meaning of religious rituals more to ceremonial events. This tendency is seen in Fangsheng or Life Release (releasing living things). In essence Fangsheng is saving the lives of living beings or animals that are destined to be killed. This Fangsheng is accompanied by certain rituals such as weddings, social services, and holidays. The urge to do Fangsheng can be seen on Buddhist sites like the one on the www.tionghoa. info and Palyul Nyigma Indonesia website (www.palyulid.org). This article presents the definition of Fangsheng, the Buddhist utterance for radiating love by loving living beings, how to do Fangsheng, and the benefits of Fangsheng. How to do Fangsheng is done to give the Fangsheng definition as follows:

... saving lives ... paying back debt ... helping emergency situations ... compassion ... realizing awareness ... practice ... gathering benefits ... comfortable ... changing one's destiny ... removing bad karma relationship ... erasing bad luck ... healing illness ... saving family and relatives ... extending one's life ... blessing .... helping someone be born in the Buddha's Pure Land.[3]

On the one hand, this description makes it clear that Fangsheng is not only done by releasing animals in cages into the wild as is often done now, but also helps save others who are sick or hit by difficulties. Therefore, Fangsheng should be done spontaneously if you find these things. However, the illustration that is displayed in general

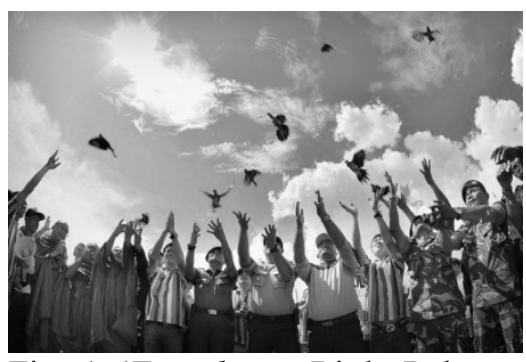

Fig. 1 (Fangshen - Birds Release, https://www.inibaru.id/tradisinesia/ mengenal-tradisi-fang-shen-bagimasyarakat-tionghoa)

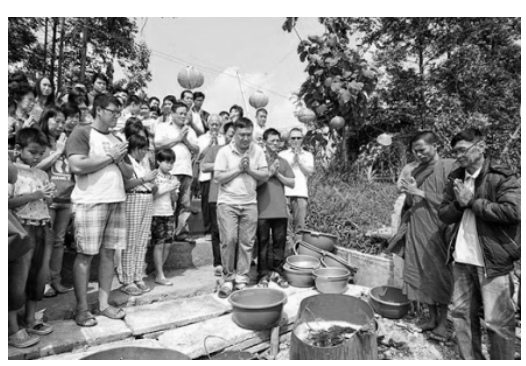

Fig. 2 (Fangshen - Fishes Release, http://www.dhammacakka.org/?cha nnel $=$ info\&mode $=$ detailgaleri\&id $=$ 37)

Fangsheng is more ceremonial, releasing birds or fish together.

Looking at what is suggested to do Fangsheng like this cannot be said to be wrong. However, in seeing discourse, the problem is not only seen what is there. But also in what is not there. As a result, much of the Fangsheng is contrary to its true meaning. The existence of the Fangshen tradition actually preserves the sale and purchase of animals because in the market there is a need for animals to be released as described in the article "Rezeki dari Tradisi Melepas Burung”.[4]

Traditions that actually aim to save sentient beings and develop 
compassion actually pose a threat to the life and freedom of animals. This happens because in order to carry out the tradition, they order animals in large quantities to animal sellers so that the animal sellers hunt to fulfill the demand. Other threats arise when the release of animals is not in accordance with the natural environment of the animal so that it can threaten the ecosystem. This happens a lot to Fangsheng by releasing fish. This is actually contrary to the teachings of Buddha as contained in Dhmmapada 270, "One cannot be called Ariya (noble person) if one is still torturing living beings. He no longer torments sentient beings that can be said to be noble. "Therefore, the invitation to do Fangsheng needs to be done with wisdom as stated in the article 'Tips Melakukan Fang Sheng dan Jiu Sheng yang Tepat dan Bermanfaat"' (www. kadamchoeling.or.id).[5]

In order for Fansheng to truly help sentient beings, these steps need to be considered: generate virtuous motivation; avoid ordering animals to be released; select the appropriate release location; be careful when handling animals; and release animals in a reasonable amount. As the Buddha taught in Dhammapada X-131, "People who seek happiness in oppressing other sentient beings who also want to be happy will not get the happiness that they seek." In this case, it is seen that the texts of Buddhist teachings need to be explored continuously to reflect the essence of a ritual.

On the other hand, contextualization of events needs to be done wisely so that the text can be understood properly. The article "Terjadinya Banjir adalah Buah Kamma Buruk" relates the flood events that occurred in early 2020 with Stories Vidudabha.[6]

However, on the fourth occasion, the Buddha could no longer save his family from destruction because their bad kamma in the past was bearing fruit. This bad kamma was created in the past life of the Sakya Tribe. In a life, Sakya Tribe is known to have been born as a group of fishermen.

To get fish easily, they sprinkle poison into the river. There are so many fish that die from these poisons. One of them is Vidudabha. Before dying, the fish that would later be born Vidudabha hold a grudge and vow to repay the actions of the fishermen.

The hatred so deeply rooted eventually led to mass murder in the next life.

Even though certain bad kamma may be bearing fruit when a flood arrives, it does not mean kamma is the only factor that causes the disaster. There are still other factors that could be the cause.

In order to continue to survive in the midst of a disaster, we should be introspective. This attitude makes us aware of the mistakes that have been made, so that we have the opportunity to fix it before it's too late.

Don't be like King Vidudabha, who forgets introspection. Because he thought the killing he had done was right, he and his troops were 
eventually killed in a tragic way.

After destroying the Sakya Tribe, King Vidudabha's army then stayed overnight on the banks of the river Aciravati. Due to fatigue after fighting, they immediately fell asleep. They did not realize that it was their last night. Because, not long after, a sudden flood came to drown them all.

Again, in that event, karma played its role.

In this case, the textualisation of events needs to be criticized with regard to karma resources, namely cause (textual) related to the origin of the Buddha's utterances and actions (actions), which includes the impact of thoughts and actions.[7] Thus, textual manipulation that leads to false awareness can be spared. In relation to flood events, social karma should be more directed to how each responds to flooding because each individual must have a different response. Flooding can lead to an inner reflection of the "flood of desires" that cause consumerism and threats to environmental sustainability.

\section{Concluding Remark}

The Fangsheng ritual is very popular in the Indonesian Chinese Buddhist community, with various Buddhist backgrounds they believe in. The ritual of the release of living beings is believed to be an act that forms good kamma in later life (reincarnation) also believed to bring prosperity and happiness in the lifetime of this world. Business, career, and family life will more easily and smoothly obtain and achieve happiness. This ritual usually releases birds, turtles and fish. Living creatures of animals are released into their respective habitats with the assumption that they can re-drink the wild and happy.[8]

However, the present situation is very different from the past where not many people live themselves in bond with nature (as farmers, fishermen, hunters), and nature is no longer friendly due to climate change which is an act of 'modern' humans who have damaged it, making Buddhists began discussing Fangshen's discourse. By looking back and reflecting on Gautama Buddha's teachings by seeing the changing natural realities and wrong practices due to hidden economic motives that infiltrated the sacredness of a ritual like Fangshen began to be understood and interpreted with new interpretations and actions.[9]

\section{Acknowledgment}

We would like to appreciate the very insightful and enlightenment discussion, criticism, and suggestions with Bhante Suryanandhi. Our most important thanks go to STAB Kertarajasa for providing full support for the academic journey following the 4th ICIIS.[] 


\section{References}

[1] Aris Badara, Analisis Wacana, (Jakarta: Prenada Media Group, 2013) h. 7.

[2] Eriyanto, Analisis Wacana: Pengantar Analisis Teks Media.(Yogyakarta: LKIS: 2001) h. xi

[3] Admin, W. (n.d.). Palyul Nyingma Indonesia-Fangshen atau Life Release atau Melepaskan Makhluk Hidup. Retrieved February 15, 2020, from http://www.palyulid. org/ajaran/item/33-Fangshen -atau-life-release-atau-melepaskan-makhluk-hidup

[4] Venusgazer EP. (2016, Agustus). Rezeki dari Tradisi Melepas Burung. https://www. kompasiana.com/venusgazer/57b4c1a71 fafbd7844a7c4ab/rezeki-dari-tradisi-melepasburung

[5] Anonymous. (2018, October 5). Tips Melakukan Fang Sheng dan Jiu Sheng yang Tepat dan Bermanfaat. Kadam Choeling Indonesia. https://www.kadamchoeling.or.id/tipsmelakukan-fang-sheng-dan-jiu-sheng-yang-tepat-dan-bermanfaat/

[6] Wirawan, A. (2020, January 12). Terjadinya Banjir adalah Buah Kamma Buruk? BuddhaZine. https://buddhazine.com/terjadinya-banjir-adalah-buah-kamma-buruk/

[7] Wawancara dengan Bhante Suryanandhi, Jakarta, 14 Februari 2020

[8] Zhang, A. (2011, July 7). Fangsheng 放生-Tradisi Melepaskan Binatang. http://web. budaya-tionghoa.net/index.php/item/924-fangsheng-放生-tradisi-melepaskan-binatang

[9] Tan, H. (2013, July 23). Tradisi Fang Sheng, Antara Ritual Dan Pelestarian Satwa | Tionghoa.INFO - Tradisi dan Budaya Tionghoa. https://www.tionghoa.info/tradisi-fangsheng-antara-ritual-dan-pelestarian-satwa/ 